\begin{tabular}{|lcccccc|}
\hline $\begin{array}{l}\text { Social Work/Maatskaplike } \\
\text { http://socialwork.journals.ac.za/pub }\end{array}$ & Werk & $\begin{array}{c}\text { Vol 51 No 3; Issue } \\
\text { doi:http://dx.doi.org/51-3-453 }\end{array}$ & 3 \\
\hline
\end{tabular}

THE EXPERIENCES OF SOCIAL WORKERS IN THE PROVISION OF FAMILY PRESERVATION SERVICES

Felistas Nhedzi \& Mankwane Makofane

This paper discusses the experiences of twelve social workers as providers of family preservation services. The sample was selected through purposive and snowball sampling. Data were collected through face-to-face semi-structured interviews, which yielded rich information on a host of challenges experienced by social workers. Some of the challenges entail the parents' reluctance to participate in family preservation services, their unwillingness to care for their children, non-adherence to intervention plans, protection of perpetrators of child abuse by family members, traditional practices, lack of resources and low salaries. These challenges have an adverse effect on the morale and wellbeing of social workers. 



\section{THE EXPERIENCES OF SOCIAL WORKERS IN THE PROVISION OF FAMILY PRESERVATION SERVICES}

\section{Felistas Nhedz, Mankwane Makofane}

\section{INTRODUCTION AND BACKGROUND}

Families with vulnerable children experience multifaceted challenges that require appropriate intervention. It is important to note that these families have strengths, resilience and resources which social workers need to identify and utilise to assist family members (Manual on Family Preservation Services, 2010:iv). The roots of family preservation services are traced back to the home-builders model which started in the 1970s in California in the USA (Berry, 2005:320; Cash, 2008:471; Gandarilla, 2009:21). This model arose from a need to provide home-based services to families and children involved in the child welfare system (Janzen, Harris, Jordan \& Franklin, 2006:55), especially families whose children were at risk of placement outside of the home (Janzen et al., 2006:55; Zastrow, 2008:202). The key characteristics of the model include contact with the family within 24 hours of the crisis; small caseload sizes for workers; service duration of four to six weeks; and intensive service delivery (Cash, 2008:472; Tully, 2008:iii).

Different forms of family preservation services include family-centred services, intensive services and family-support services. Family-centred service (FCS) is regarded as a philosophy and method of service delivery which emphasises the partnership between parents and service providers so that families are involved in the rendering of services for their children (Law, Hanna, King, Hurley, King, Kertoy \& Rosenbaum, 2003:357). These services involve a broad approach to helping families in various fields (Madsen, 2009:103). Children are part of families, hence the family context requires consideration during the provision of social work services. Furthermore, families are not seen as clients receiving services, but rather as partners in making decisions about goals and activities (Bailey, Raspa \& Fox, 2012:217). Core principles of a family-centred approach that are similar to family preservation include focusing on family strengths, respecting family diversity and values, encouraging family decision-making and empowerment, communicating with families in an open and collaborative fashion, adopting a flexible approach to service provision, and recognising the value of informal support systems (Bailey et al., 2012:217).

It should be noted that preventative services are categorised as family support services, not as family preservation services (Berry, 2005:319; Popple \& Leighninger, 2008:315). Thus the distinction between family support services and family preservation services is that the former services are available to any family that seeks them and not necessarily because they have experienced child maltreatment (Berry, 2005:319).

Generally, family preservation services empower families to enhance the optimal development of needy children and to prevent their statutory removal from families to alternative care (Strydom, 2010:192). Furthermore, services focus on strengthening families, keeping family members together, and encouraging parents to take 
responsibility for raising their children (Crosson-Tower, 2009:244; Green Paper on Families, 2011:74; Swart, 2012:24). At the prevention level, family preservation services seek to enhance the capacity of families to take care of their children, thus preventing child maltreatment (Popple \& Leighninger, 2008:315; White Paper for Social Welfare, 1997:64; White Paper on Families in South Africa, 2012:38). The aim is also to improve the family environment, thus supporting the child-rearing capacity of families and the community at large (Matthias \& Zaal 2009:291; Popple \& Leighninger, 2008:315). The long-term national strategic plan of the National Department of Social Development (DSD) is to broaden the provision of prevention services, which will in turn narrow the need for provision of early intervention, statutory and aftercare services (DSD National Strategic Plan, 2013:7).

On the other hand, intensive family preservation services are offered to families with children who have experienced maltreatment and are at risk of being removed from their homes (Berry, 2005:319). In this case, intensive therapeutic or psycho-social services are rendered to strengthen the family functioning and self-reliance, thus promoting stability and avoiding the removal of the child from home to an alternative placement (Berry, 2005:319; Manual on Family Preservation Services, 2010:46; Strydom, 2010:192). Focus is placed on helping families to develop coping mechanisms to carry out their child-care responsibilities during the crisis period (Strydom, 2010:192,194), thus making the statutory removal of children from home the "last resort" after all efforts to retain vulnerable children within their families have been exhausted (DSD National Strategic Plan, 2013:3). Most cases handled by the participants fell into this category.

\section{THE SOUTH AFRICAN CONTEXT}

Within the South African context renewed and enhanced efforts to strengthen and preserve needy families have been instituted through national policy development (Gray \& Lombard, 2008:134). The South African government formulated the White Paper for Social Welfare (1997) after the advent of democracy in 1994 with the understanding that poor families are struggling to meet the needs of their children and that their situation requires immediate intervention (Green Paper on Families, 2011:5; Matthias \& Zaal, 2009:291). By adopting a developmental approach to social welfare, government sought to "enhance the well-being of the poor and the disempowered" families by enhancing their participation in activities that promote economic justice (Bak, 2004:81,89; Patel, 2005:2; Patel, Schmid \& Hochfeld, 2012:214). As a result, the focus has been on family preservation services to restore family functioning and enable needy families to carry out their child-rearing roles and responsibilities (Green Paper on Families, 2011:5).

Notably, South African legislation provides for the delivery of family preservation services at four levels of intervention which social workers are required to concentrate on:

- Prevention enhances the capacity, roles and responsibilities of families; 
- Early intervention stabilises the crisis experienced by children that could cause their removal from home;

- Statutory intervention assesses and identifies the needs of families while they are awaiting the court's outcome on the statutory removal of a child or a family member; and

- Aftercare intervention addresses risk factors that led to the removal of a child or family member and to facilitate the development of stable, reliable and wellfunctioning families (DSD strategic plan, 2013:3; Manual on Family Preservation Services, 2010:47; White Paper for Social Welfare, 1997:64; White Paper on Families in South Africa, 2012:38-39).

The therapeutic or rehabilitation services offered by social workers should include community work projects or income-generating programmes from a strengths perspective (Manual on Family Preservation Services, 2010:iv; Strydom, 2010:197; Swart, 2012:24). The goal is to enable parents to consolidate their strengths and capacities to take care of their own children with support from the social workers (Saleebey, 2013:18).

Statutory family preservation services are guided by the Children's Act No. 38 of 2005 (2006, section 150-151) that provides conditions under which children in harmful circumstances are, or may be considered to be in need of care and protection. It also provides for the statutory removal of abused children to alternative care and for the removal of perpetrators. An order may be issued to mandate family members to attend a family preservation programme such as drug rehabilitation, parenting skills training or anger management, while the child remains in parental or alternative care.

However, previous studies showed that social workers had insufficient contact with families due to high caseloads, thus exposing vulnerable family members to further harm (Krane, Davis, Calton \& Mulcahy, 2010:158-159; Mashigo, 2007:91; Matthias \& Zaal, 2009:296). The shortage of social workers led the then Minister for Public Service and Administration, Ms Geraldine Fraser-Moleketi, to declare social work as a scarce skill in 2003, but this was not legislated (Earle, 2008a:66,80; Recruitment and Retention Strategy for Social Workers in South Africa, 2006:14). To address the shortage of social workers, the DSD has developed a recruitment and retention strategy through which social work students are granted bursaries to pursue their studies. After completion, the beneficiaries of the bursary are placed by the national or provincial DSD that provided the funding.

However, the shortage of funding for programmes in organisations, unemployment in families and community income-generating projects continues to overwhelm social workers (Bak, 2004:90; Sewpaul \& Hölscher, 2007:198). Despite a lack of resources, Gray and Lombard (2008:137-139) noted that some social workers continue to prioritise family preservation services. For instance, in their quest to provide family preservation services, some of the Ekurhuleni social workers made attempts to avoid the removal of 
vulnerable children from their homes and placing them in Kids Haven and the Child and Youth care centres.

But during the Ekurhuleni Welfare Social Services and Development Forum (26 March 2012) in Benoni (Gauteng Province), the representatives of Child and Youth Care Centres accused the provincial DSD social workers of removing children from families without first rendering early intervention family preservation services. It was further claimed that children are merely "dumped" at care centres, resulting in social workers being followed up and persuaded to attend and participate in discussions on the establishment of the children's future intervention and reunification plans with care centres (Ekurhuleni Welfare, Social Services and Development Forum, 2012a). In cases where children were reunited with their families, the three to six months follow-up audits conducted by social workers at the care centres revealed that, the situation of the children who were reunited with their families by social workers based in communities (employed by the provincial DSD), had deteriorated to a point where they were repatriate to care centres.

Organisational problems have been identified as the causes for the confusion and ineffectiveness among social workers, such as insufficient training, lack of role clarity, inadequate leadership, unrealistic expectations by the DSD, lack of resources or funding and low salaries (Bak, 2004:83; Gray \& Lombard, 2008:135; Landman \& Lombard, 2006:2; Mashigo, 2007:90; Matthias \& Zaal, 2009:295). Insufficient training led to misconceptions, misunderstandings and role confusion among social workers regarding social work services as outlined in the new South African legislation (Mashigo, 2007:90).

In addition, some of the identified challenges relate to lack of leadership in providing direction to social workers on how to effectively respond simultaneously to the demands of statutory work (e.g. foster care), family preservation and community development services (Landman \& Lombard, 2006:2; Mashigo, 2007:95). Thus, the few available social workers are overloaded with legislative responsibilities such as the investigation of many foster care cases and the compilation of reports, which lead to an emphasis on paperwork and meeting court deadlines (Krane et al., 2010:158-159; Mashigo, 2007:91; Matthias \& Zaal, 2009:296). Consequently, social workers become frustrated, insecure, sceptical, disillusioned and anxious instead of being the major role players in addressing the needs of South African society (Cock, 2008:114; Mashigo, 2007:14).

Lack of funding in non-governmental organisations (NGOs) has been a topical issue in the media (Davids, 2012:6; e.tv, 2012). According to Davids (2012:6), organisations across South Africa are struggling to continue providing crucial services to children and their families, yet government disclosed a lack of knowledge about the severity of funding shortages overwhelming the NGOs. Subsequently, the DSD described lack of funding as a "crisis" that had disempowered many organisations, leaving others on the verge of collapse (Minister probes NGOs' funding crisis, 2012:22). Another example worth noting is the e.tv programme shown on 19 April 2012, which reported that in Boksburg (Ekurhuleni metropolitan area), the child welfare unit had one social worker 
handling 250 cases a month, while newly qualified social workers were unemployed because of a lack of funding (e.tv, 2012).

The severity of the lack of funding for NGOs in Ekurhuleni metropolitan area became evident during a meeting of the Ekurhuleni Welfare, Social Services and Development Forum in Benoni (6 May 2012). Here social workers registered a concern that, unless welfare organisations receive sufficient funds from the DSD, the requirements of the Children's Act No. 38 of 2005 to provide family preservation services will not be met (Ekurhuleni Welfare, Social Services and Development Forum, 2012b).

Hence, insufficient resources in families and communities continue to challenge social workers who are expected to ensure that children stay within families despite the poverty (Bak, 2004:90; Sewpaul \& Hölscher, 2007:198). For instance, most at-risk children in Ekurhuleni are from poverty-stricken families and communities. In 2011 almost two thirds of more than seven million children in South Africa lived below the poverty line with a monthly household income of less than R604 (Hall, 2013:90-91). Families are unable to meet the basic needs of their children, thus making them vulnerable to neglect, and emotional and sexual abuse (Collins, Jordan \& Coleman, 2007:22; Green Paper on Families, 2011:5; Matthias \& Zaal, 2009:291). Even though social workers may educate parents on these issues in an effort to keep children in their families, poverty continues to render their efforts ineffective and futile. Thus, working in under-serviced, povertystricken communities experiencing a high unemployment rate, becomes a major challenge (Matthias \& Zaal, 2009:29; Ravestijn, 2001:6; Strydom, 2010:199).

Social workers within the child protection sphere also face challenges when providing services to children and families living in a risky environment (Bywater, 2008:45). Ekurhuleni metropolitan area is situated in Gauteng, which recorded the highest number of crimes against children (Violence against children in South Africa, 2012:10). The prevalence of crime and domestic violence in Ekurhuleni makes the area unsafe for its residents. Even though social workers endeavour to provide intensive family preservation services (IFPS), the complexity of the South African situation means that the country is not at a stage where it can confidently implement services as has been done in developed countries.

The rationale for the study was to explore and describe the social workers' experiences in the provision of family preservation services (Green Paper on Families, 2011:67; Mashigo, 2007:90). The study was conducted in 2013 in the Ekurhuleni metropolitan area after ethical clearance was obtained from the Department of Social Work at the University of South Africa (Unisa) and subsequently permission to conduct the study was granted by the Gauteng provincial DSD and the management of three child welfare organisations.

\section{RESEARCH QUESTION AND GOAL}

The research question provided the starting point for the research process and facilitated the determination of the goal (Royse, 2008:21; Yegidis \& Weinbach, 2002:56). The overarching research question for the study was: What are the challenges experienced by social workers during the provision of family preservation services in the Ekurhuleni 
metropolitan area? The goal that the researcher wanted to achieve through the research process (Hennink, Hutter \& Bailey, 2011:34) was to gain insight into the challenges experienced by social workers during the provision of family preservation services in the Ekurhuleni metropolitan area.

\section{METHODS}

The study was qualitative and assisted in the understanding of the participants' multiple perspectives based on their subjective experiences, behaviour and knowledge of the phenomenon (Creswell, 2009:176; Monette, Sullivan \& De Jong, 2008:224). The exploratory-descriptive strategy was employed as a result of the limited information (Durrheim, 2006:44; Marshall \& Rossman, 2011:69; Rubin \& Babbie, 2010:41). The contextual design, on the other hand, provided an understanding of the Ekurhuleni metropolitan milieu in which social workers render family preservation services.

The metropolitan area has a total population of 3178470 (City of Ekurhuleni, 2013:9). More than one third (39.4\%) of the population is made up those who are 0 to 14 years and 65 years and above, and they are dependent upon the working population aged between 15 and 64 years (Statistics South Africa, 2012:12). Despite the high ratio of dependants, the unemployment rate among the working population is $3.2 \%$ higher than the national unemployment rate of 25.6\% (City of Ekurhuleni, 2013:9).

A combination of purposive and snowball sampling was used to identify and recruit participants who have been involved in the implementation of family preservation services within the Department of Social Development (DSD) and child welfare organisations for a minimum of 12 months and were willing to take part in the study. Semi-structured interviews were digitally recorded with the consent of the participants. The data were transcribed and analysed by the authors following Tesch's eight stages (Creswell, 2009:186). In addition, an independent coder used the Atlas Ti software package to analyse data and thus the team effort enhanced the credibility of the findings.

\section{FINDINGS}

The biographical data of twelve participants are presented in Table 1 followed by a discussion on the themes and issues that impede the provision of family preservation services. 
TABLE 1

BIOGRAPHICAL PROFILE OF THE PARTICIPANTS ${ }^{1}$

\begin{tabular}{|c|c|c|c|c|c|c|}
\hline $\begin{array}{c}\text { Partici- } \\
\text { pant }\end{array}$ & Age & $\begin{array}{c}\text { Gender } \\
\text { F = female } \\
\text { M = male }\end{array}$ & Race & $\begin{array}{c}\text { University from } \\
\text { which a BSW } \\
\text { degree was } \\
\text { obtained }\end{array}$ & $\begin{array}{c}\text { Duration of } \\
\text { employment } \\
\text { (providing } \\
\text { family preser- } \\
\text { vation } \\
\text { services) }\end{array}$ & Position \\
\hline A & 28 & F & White & $\begin{array}{c}\text { University of } \\
\text { South Africa }\end{array}$ & $5(5)$ & Social worker \\
\hline B & 38 & F & African & $\begin{array}{c}\text { University of } \\
\text { Zululand }\end{array}$ & $11(11)$ & Senior social worker \\
\hline C & 28 & F & African & $\begin{array}{c}\text { University of the } \\
\text { Witwatersrand }\end{array}$ & $2(2)$ & Social worker \\
\hline D & 30 & M & African & $\begin{array}{c}\text { University of } \\
\text { Zimbabwe }\end{array}$ & $6(3)$ & Social work manager \\
\hline E & 34 & F & African & $\begin{array}{c}\text { University of } \\
\text { Zululand }\end{array}$ & $5(5)$ & Social worker \\
\hline F & 26 & F & Asian & $\begin{array}{c}\text { University of } \\
\text { Johannesburg }\end{array}$ & $4(4)$ & Social worker \\
\hline G & 31 & M & African & $\begin{array}{c}\text { University of } \\
\text { Zimbabwe }\end{array}$ & $7(7)$ & Social worker \\
\hline H & 33 & F & African & $\begin{array}{c}\text { University of } \\
\text { South Africa }\end{array}$ & $11(5)$ & Social worker \\
\hline I & 41 & F & African & $\begin{array}{c}\text { University of } \\
\text { Fort Hare }\end{array}$ & $11(10)$ & Social worker \\
\hline J & 29 & F & African & $\begin{array}{c}\text { University of } \\
\text { South Africa }\end{array}$ & $7(3)$ & Social worker \\
L & 29 & F & White & $\begin{array}{c}\text { University of } \\
\text { South Africa }\end{array}$ & $5(1)$ & Social worker \\
Potchefstroom & Foloured & University of & $14(8)$ & Social worker \\
\hline
\end{tabular}

The ages of the participants ranged from 28 to 41 years, with a mean age of 32 . The ages of eleven participants were between 28 and 38 years. This is a critical stage of development at which individuals are expected to develop intimate relationships outside the family (Walker \& Crawford, 2010:29). Thus professionals need to strike a balance between their personal and professional demands.

${ }^{1}$ Names of social work offices are excluded to protect the identity of the participants.

Social Work/Maatskaplike Werk 2015:51(3) 
Three major themes and sub-themes that emerged from data analysis are presented in Table 2 below.

\section{TABLE 2}

\section{THEMES AND SUB-THEMES}

\begin{tabular}{|c|c|}
\hline $\begin{array}{l}\text { THEME } 1 \\
\text { Challenges experienced by } \\
\text { participants when providing services } \\
\text { to families }\end{array}$ & $\begin{array}{l}\text { - Difficulties in engaging parents } \\
\text { - Parents' reluctance to care for their children } \\
\text { - False and/or inadequate information provided } \\
\text { - } \text { by families } \\
\text { - } \text { Non-adherence to an intervention plan } \\
\text { - Perpetrators of child abuse } \\
\text { - Cultural issues among family members }\end{array}$ \\
\hline $\begin{array}{l}\text { THEME } 2 \\
\text { Barriers to effective family } \\
\text { preservation services }\end{array}$ & $\begin{array}{l}\text { - Lack of specialised services } \\
\text { - Lack of clear guidelines and training for social } \\
\text { - } \text { Inorkers } \\
\text { - } \text { resourficient funding and organisational } \\
\text { - } \text { High caseloads and low salaries } \\
\text { - } \text { Lack of supportive services for social workers } \\
\text { - } \quad \text { Lack of inter-organisational cooperation }\end{array}$ \\
\hline $\begin{array}{l}\text { THEME } 3 \\
\text { The impact of the challenges and } \\
\text { barriers to service delivery on the } \\
\text { participants }\end{array}$ & \\
\hline
\end{tabular}

The findings are compared with the literature on intensive family preservation services, since social workers made an effort to offer such services to families with children who have experienced maltreatment and were at risk of being removed from their homes (Berry, 2005:319).

\section{THEME 1: Challenges experienced by participants when providing services to families}

Social workers face myriad challenges with families, communities and organisations which frustrate their efforts in the provision of family preservation services (Bak, 2004:90; Earle, 2008b:32; Sewpaul \& Hölscher, 2007:198; Strydom, 2010:200). Seven challenges that impact negatively on service delivery were reported as difficulties in engaging parents; parents' reluctance to care for their children; false and/or inadequate information provided by families; non-adherence to an intervention plan; lack of improvement in the client system; perpetrators of child abuse; and cultural issues among family members. 


\section{- Difficulties in engaging parents}

The success of family preservation services relies on the cooperation of family members with the service providers. However, the subtle resistance of parents was encapsulated as follows: "The parents have this push away thing [rejection] like I do not want a social worker in my life." It has also been found in the past that family members' resistance and lack of cooperation had a negative impact on the provision of family preservation services (Sandoval 2010:36-37; Strydom 2010:200). However, in their study Grockel, Russell and Harris (2008:97-98) found that "Parents described how staff in helpful programmes communicated attitudes, beliefs, and behaviours that allowed them to see themselves as valued, respected and cared for, and that made it easier for them to receive assistance and take risks to make changes."

The clients' involuntary participation is attributed to their reluctance to take part in family preservation programmes. One participant said: "The people who are actually instructed by the court or requested by the social worker to attend [the family preservation programme] I struggle with them. They do not come for sessions. I have to phone them continuously and even after that they will not show up."

The resistance of involuntary clients to work towards the goals set by the social worker or authorities has been highlighted by several authors (Birkenmaier, Berg-Weger \& Dewees, 2011:137; Collins, Jordan \& Coleman, 2010:282; Grockel et al., 2008:104; Sandoval, 2010:36-37). Even though the affected individual is likely to benefit from mandated professional intervention, lack of readiness and willingness to engage with the worker thwart all efforts. Therefore, social workers should establish a non-threatening relationship with resistant clients and strive to win their confidence through education on the essence of their participation and likely benefits from the intervention.

Despite the fact that Ekurhuleni is a metropolitan area where many people have access to print and electronic media, misconceptions about the roles and functions of social workers are prevalent. Involuntary clients were reported to hold negative perceptions towards social workers as people who interfere in their lives by: removing children from their homes; associating with the police; and suspected them of acting upon allegations made by clients' neighbours.

"...the parents really feel that; why are you mixing [meddling] in their lives; why are you here in their lives, making their life difficult?"

"...mostly it appears like people view us in a bad light as people who are there to remove their children."

"Maybe it is because when they are called [by social workers] to report at our offices, the first thing they tell themselves is that they have been arrested and reported to the social workers."

"...sometimes they feel that they are being victimised, because they are poor or they are being victimised because... maybe their neighbours called you because they are not on good terms with them." 
Similarly, Grockel et al. (2008:104) reported that parents exhibit feelings of anger and fear towards child welfare workers. In addition, working with involuntary clients might be uncomfortable for some social workers (Birkenmaier et al., 2011:137) as reported by one participant: "You find that in some instances progress cannot be made because there is somebody in the family who is not willing to participate..."

Conversely, assertive family members wanted to know the benefits of their participation in the programme as pointed out by a participant: "...they [family members] would want to know what is it that they are going to benefit? For example, is there food or free gifts that we are gonna give them for attending? " The latter is a contentious issue in instances where organisations are cash strapped and unable to provide incentives (Davids, 2012:6; Dlangamandla, 2010:90; e.tv, 2012; Strydom, 2010:200).

Some parents were described by participants as showing a lack of understanding and insight into their situation and failure to appreciate social work intervention.

"They are not interested in our services."

"I think to us it is a lack of seriousness...."

"She does not really value what we are trying to do, in terms of giving her parenting skills."

"...they do not always see that they have a problem. They do not see the reality of the situation."

On the other hand, Cash and Berry (2003:21) attribute parents' lack of participation and attendance in family preservation programmes to service providers' failure in establishing a good working relationship with families. Coulshed and Orme (2012:130) also assert that when families are confronted with problems, they are more receptive to help as they would be seeking strategies to resolve their problems and restore their level of functioning.

\section{- Parents' reluctance to care for their children}

Challenges in parenting raise a sense of hopelessness, passiveness and pessimism which may dishearten parents from carrying out their child-care responsibilities (Collins et al., 2010:265). Similar experiences were aptly explained by the participants.

"...parents say no, we do not want the child anymore; place the child somewhere...they are pushing their responsibility to social workers.... see to finish on what to do with this child, you know."

"...like mothers dumping kids at our offices because they are tired or the kids are naughty or they cannot discipline them enough."

One participant regarded government's initiatives as creating dependence among parents who abdicate their responsibilities of caring for their children. She said: "I think it is this thing we have created, a dependent nation that is depending on government while government does not have resources to fulfil all these needs. We need to move away from state grants and pensions. I do not know how to put it but, there is a lack of many things in the system, like I am trying to prevent the child from going through the system [child welfare institutions] by providing resources such as food and clothing but the 
parent never learns to stand on his/her own. You cannot give them food forever. At some point they have to obtain their own food."

Dependence on social workers and government incapacitate individuals as they fail to recognise and utilise their inner strengths for the improvement of their circumstances (Collins et al., 2010:270; Integrated Service Delivery Model, 2006:16-17). Hence, Patel et al. (2012:220) are of the view that the development of self-sustainable incomegeneration projects through micro-economic development interventions is a prerequisite with regard to improving the wellbeing of families.

\section{- False and/or inadequate information provided by families}

Information provided by family members during intake may under-estimate or overestimate the severity of the risk; hence workers should rely on their own assessments (Maccio, Skiba, Doueck, Randolph, Weston \& Anderson, 2003:6). The participants shared how children told lies in order to be removed from their mother's care and also pointed out the disadvantage of relying on intake information.

"So the kids told lies about the mother, that she drinks alcohol, drives them around when drunk; take them to the bar and dances on top of the table...."

"Come Tuesday, the lawyers were on my back. Did you take the children for medical assessment? Did you do this; did you do that and I did not do it; I just listened to what the kids were saying."

Before providing services, it is advisable for social workers to request additional information from clients and not to rely on exclusively what was provided during intake. Thus, social workers should facilitate the process of getting to understand the presenting problem (Anderson, 2013:191).

\section{- Non-adherence to an intervention plan}

A participant described the volatility of the clients' situations which makes it difficult to follow an intervention plan and has far-reaching implications. One participant said:

"You can have the time frame to say I am monitoring my families that are on family preservation on a fortnightly basis, for example, but during that fortnight you can hear stories. I had a child in 2010 who was part of a family preservation group programme focusing on addressing his behavioural problems while he was in parental care. He burnt himself [to harm himself]..... They tried to rush him to a medical hospital but it did not help; he passed away. Sometimes I think and feel maybe we were supposed to have removed him while we were offering family preservation services. We were really supposed to remove the child but we just thought it was general child behavioural problems."

The social workers' intervention plan may have negative effects on the children and families involved, since professionals often face the dilemma to either let the children 
remain in their vulnerable family environments or to find them alternative placements (Bywater, 2008:45; Holland, 2011:50).

\section{- Lack of improvement in the client's system}

The participants associated failure of improvement in the clients' circumstances to child neglect, substance abuse by parents, and negative environmental factors.

- Child neglect - "....the same parents did the same thing again. They left their children alone”; "...you get frustrated because much as you might want to see yourself succeeding with your client and following up your client until you see that, yes, that is my product [my achievement]"; "you cannot" [see the positive outcomes of your work]. Cash and Berry (2003:22) caution that intensive family preservation services do not necessarily contribute to successful case closure or positive changes in child and family systems.

- Substance abuse by parents - "Some things are out of our control; the issues of drugs ... if a mother is taking drugs there is no way that she can look after her own child properly; no matter how much advocacy and counselling you might offer, if they are high on drugs, no ways, no ways..." Similar negative results on the provision of family preservation services, due to mothers being addicted to substances, were reported by Sandoval (2010:49).

- Environmental factors - “...problems that we are facing are macro-economic. So it is like you are treating a person and then taking them back to the same community which infected them...the same place or environment where they got their infection has not changed." "Like there is crime....too much crime, poverty, unemployment and all that... have a negative impact on our services as social workers. Even if we try our level best to educate them [parents] through awareness programmes and strengthen them in whatever way, crime, poverty and unemployment will always affect us." Environmental aspects such as crime, poverty and unemployment, have a negative impact on families and cannot be ameliorated by a short-term intensive programme such as family preservation (Cash \& Berry, 2003:22).

\section{- Perpetrators of child abuse}

The Children's Act No. 38 of 2005 (2006:section 153) provides for perpetrators of child abuse to be removed from the home instead of ordering the removal of the child to alternative care. However, participants described difficulties in executing their duties where incidents of child abuse were reported. One participant stated that: “...our justice system is failing us because in such cases you will find that the perpetrator is not sentenced [to prison]. The perpetrator is sent back to the family and then you cannot leave the child in such a family where the same person who sexually abused the child still lives."

It has been noted that some parents are fearful and ashamed to be associated with child abuse and are often resistant to family preservation services (Grockel et al., 2008:104). Thus, social workers have to either leave a child in a dangerous family environment or 
move the child to an alternative placement, which is unfavourable according to the family preservation approach (Rycus \& Hughes, 2008:201). Unfortunately, a disheartening report by Swart (2012:24) in the Mail \& Guardian newspaper suggested that recommending imprisonment of the perpetrator in family preservation in South Africa is not an alternative, since perpetrators are released on the basis that the prisons are full.

Furthermore, the participants mentioned that perpetrators may enjoy the protection of their partners and/or family members.

"...mothers comes forward and defending their husbands or boyfriends...when the child is saying I was abused by my father, the mother will say, no ways."

"Family members do not want the abuser to be arrested. So they will try to protect the perpetrators from going to prison and that is a challenge, you know."

Jones and Morris (2007:225) caution that if a family member supports a perpetrator and disbelieves the child (who is the victim), the child's identity, self-worth and experience of love will be affected. Children may also be susceptible to mental and physical disorders (Repetti, Taylor \& Seeman, 2002:330).

\section{- Cultural issues among family members}

Participants identified the African cultural practice of lobola (bride price) as posing a challenge in cases where a child needs to be placed with the father.

"They [the maternal family] say we cannot let this child go [to the father] because the man has not paid lobola. Yes, the court is enforcing its orders but an order will never create peace because the other party feels aggrieved because they hold on to their culture. So we are having problems in trying to negotiate with our clients, especially when we are doing our parenting plans. They [the maternal family] will try at all cost to frustrate whatever moves you are making to ensure that the child is transferred to the father."

"...it is difficult because some families base their argument on culture. They believe that if the child is behaving in an unacceptable manner, instead of disciplining the child by withdrawing privileges, you should hit the child and that, for us is physical abuse."

The findings suggest that social workers find it difficult to utilise social work knowledge, values and skills on cultural diversity in developing cultural competence to effectively engage families across ethnic and cultural boundaries (Downs, Moore, McFadden, Michaud \& Costin, 2004:299).

\section{THEME 2: Barriers to effective family preservation services}

Even though social workers are expected to provide family preservation services, seven barriers that impede the accomplishment of this mandate were identified, namely lack of specialised services; lack of clear guidelines and training for social workers; insufficient funding and organisational resources; high caseloads and low salaries; lack of supportive 
services for social workers; political agendas; and lack of inter-organisational cooperation.

\section{- Lack of specialised services}

The participants noted the need to refer clients for specialised services such as psychological services. However, participants reported the inaccessibility of affordable psychological services as follows:

"Some hospitals [state hospitals] have psychologists, while some are understaffed. Some clinics have psychologists, but they are overworked and they do not have time to see everybody."

"You have to ferry them [clients] to the psychologist and back. When am I going to do my job, if I am going to drive clients to and from the psychologist?"

"I mean for some psychologists, one assessment cost R400 or R500 for them to see one child once."

Strydom (2010:199) established that communal resources are not accessible for families who are financially disadvantaged. On the other hand, the Green Paper on Families (2011:67) emphasises the importance of state psychologists and psychiatrists in assessing the stability of families encountering psychological problems and for providing recommendations on intervention plans.

The participants mentioned practical challenges regarding the inaccessibility of communal resources such as developmental centres, drug rehabilitation centres, children's homes, home-based care services and medical doctors. The following storylines are illustrative:

"The developmental centres only provide for certain people [who are destitute]; not the whole community is allowed to be involved in income-generating programmes."

"...you do not advertise it [feeding scheme programme] because you will be overwhelmed by the response."

"I will start with the queue to get the file, from the filing queue to the medical doctor's queue; which means the whole day I have done the medical [assessment]."

"I have not looked for a placement [children's home to place the child in need], I do not know where I will get it and whether I will find it ... the child is going back [home] to that abuse."

"You do not always have people who can help you with the drug abuse problem or have somebody who can go out and check on the family when you are not able to go out every day."

"They [home-based care organisations] are useful but they are few."

These findings support the premise that in South Africa child welfare policies have prioritised strengthening families to become self-reliant, yet there is a shortage of 
communal resources that would facilitate such a process (Sewpaul \& Hölscher, 2007:196).

\section{- Lack of clear guidelines and training for social workers}

Despite the fact that the Manual on Family Preservation Services (2010) is available with clear guidelines and comprehensive information on services that should be provided at prevention and early intervention levels, including statutory and aftercare, some of the participants stated that it lacks clarity. The manual is designed to provide training to social service providers from a strengths perspective. Both experienced and newly appointed social workers did not know about the manual and some expressed the following views:

"Like I said before, most social workers do not really understand when you say, family preservation. They do not understand, what is the aim of family preservation; why do we do it; what are the advantages? So, we end up just doing."

"Family preservation is just too vague; so you need to have specification on how you are going to conduct it. I mean it can sometimes confuse you as a worker."

"People just got modules to say, this is family preservation but the actual practical training was not given to us."

The findings are consistent with the notion that a lack of clear guidelines results in confusion and misunderstanding among social service providers, which in turn derails effective service provision (Dlangamandla, 2010:80-81; Mashigo, 2007:57). A study conducted by Patel et al. (2012:220) indicated that social workers felt ill-equipped in meeting social service legislative requirements. According to a senior staff member in the national DSD, the Manual on Family Preservation Services compiled in 2010 for the purpose of training social service providers on providing family preservation services from a strengths perspective is now under review.

\section{- Insufficient funding and organisational resources}

In addition to a lack of clarity and training on family preservation services, participants from both NGOs and government (the DSD) mentioned the following stumbling blocks:

- Lack of funding - "The organisation's authorities said that they do not have a budget for that [family preservation programme] but they expect us to render services still." Similarly, Strydom (2010:200) found that organisations have insufficient funds for social workers to initiate, run and maintain family preservation programmes. Furthermore, Dlangamandla (2010:90) states that social workers are expected to initiate programmes, yet when it comes to implementation they are told that there is no funding to run the programmes.

- Lack of organisational resources - "....the other challenge is not getting resources from the organisation, because for me to go out to the community I need resources; I need a car"; "...we do not have resources, you know. When you call 
people to attend a programme that you have organised, you take their time and you need to offer refreshments to them." The study by Strydom $(2010: 198,200)$ revealed that organisations have insufficient resources such as vehicles, which is an obstacle to the provision of family preservation services. Furthermore, the supply of refreshments is encouraged as it determines the families' attendance of family preservation programmes.

\section{- High caseloads and low salaries}

These are contentious issues, especially after the new democratic dispensation which led to multitudes of previously disadvantaged groups coming forth to solicit governmental support (Cock, 2008:84). In addition, the increase in foster care cases came as a result of children's loss of their parents as a result of AIDS-related illnesses (Manual on Family Preservation Services, 2010:32-33; South African Institute of Race Relations, 2011:1). The participants cited high caseloads as a hindrance to the provision of family preservation services.

"I think for now we have a problem of many cases that we are handling."

"At times we are under pressure with emergency cases to a point that we do not even get [the time] to do family preservation...."

Previous studies showed similar trends where a social worker had a caseload of more than 100 families and cases that tended to be crisis-oriented, which made it difficult to provide family preservation (Dlangamandla, 2010:90; Strydom, 2010:196,199). This is in stark contrast with the view of some authors that the size of caseloads should be small and intensive services should be provided to families for four to six weeks (Cash, 2008:472; Tully, 2008:iii).

The participants' inability to cope with the work demand is attributed to their having multiple responsibilities. A participant said: "I have got family preservation cases, foster care cases; I have got custody cases; I have got children's homes; so many things...you do not have time to give to one." This confirms previous findings in which social workers failed to cope with the demand to attend to statutory and family preservation services in an effective manner (Landman \& Lombard, 2006:2; Mashigo, 2007:95).

The participants employed by NGOs are disgruntled about their low salaries compared to those offered by the DSD. This is ascribed to the general feeling that social work in South Africa continues to be a low-status profession with poor salaries (Gray \& Lombard, 2008:143; Sithole, 2010). Similarly, Patel et al. (2012:223) noted the inability of the formal welfare sector to provide employees with adequate salaries.

"...but when you come to how it is arranged or how they decide to reward child welfare, it is quite disheartening. It is the least rewarding sector within the social work profession but with the most work. There is a lot of work and less pay in child welfare."

"We are not earning the same salaries as social workers employed by the Department of Social Development, yet we are doing the same job." 
In a study conducted by Strydom (2010:201), social workers recommended that government should eliminate the inequalities in salaries between the state and NGO social workers to enable the effective implementation of family preservation services.

\section{- Lack of supportive services for social workers}

Notwithstanding the failure of participants to cope with their workload, they also reported a lack of organisational support in relation to debriefing, funding and team building.

"We get so overworked but we do not have debriefing sessions, whereby we get group supervision and we are debriefed."

"...normally we are only told that if you have something that is bothering you, speak to your supervisor. My obvious question is; if it is your supervisor who is bothering you, whom do you speak to?"

"...it is not like we are not mentioning it [lack of funding for programmes] in our sectional meeting. We mentioned this all the time to our supervisors."

"We do not have team building here; we do not have a supportive system."

According to Crosson-Tower (2009:242), the provision of competent supervision to social workers is essential to meet the demands of providing effective family preservation services. Additionally, studies show that social work organisations should provide team building and supportive sessions on an ongoing basis in order to promote a positive organisational culture (Cock, 2008:105; Collins, 2008:1183).

\section{- Political agendas}

In a young democracy politicians strive to be seen to be responding to societal needs. However, some of their decisions are regarded by the participants from the DSD as an impediment in the implementation of intervention plans. One participant said: “...you have planned to do a programme on that day and when a case is reported on the media, then, your senior will say, 'There is this family that do not have documents and experiencing poverty'. Just because the case appeared on the media you are expected to drop everything and go and attend to that case. You know, politicians are not social workers, they did not train to become social workers; they do not know how we work."

Similarly, Dlangamandla (2010:86-87) asserts that social workers are challenged by the influence of political mandates on social service delivery that seem to focus on immediate results. A study conducted by Cock (2008:100) also revealed that political mandates create unrealistic expectations and exert work pressure on social workers.

\section{- Lack of inter-organisational cooperation}

Collaboration of various stakeholders allows families to have access to specialised services in the community and the multi-disciplinary team (Integrated Service Delivery Model, 2006:15). However, the participants expressed frustration following a lack of support, appalling attitudes and treatment they received from some health workers and the police. 
"When you take the child to Far East [Hospital] they will send you from pillar to post as if you are zero [nothing], the nurses do not recognise you. They scream at you as if you are crazy. If you go to the crisis centre they will tell you that they are dealing with rape cases."

"At the police station they will send you from pillar to post because nobody wants to take the responsibility of opening a case for you. At the place of safety they will not take the child without the J88 [a form completed by a medical health practitioner after a thorough physical examination to determine if the child was sexually or physically abused]. You will handle one case the whole week, begging the police, begging the doctor, and begging health care providers."

"So we end up being beggars, asking them [police officers and health workers] can you help us with this child, can you please, can you please, as if it is not their job."

"So, I think we end up working in a vacuum where it is just us who are expected to do everything; who are expected to mend families, of which some family problems need the police; some family problems need a different organisation, a different professional; some need lawyers; while some things need doctors...."

Congruent with these findings are those of Maccio et al. (2003:8), who report on the frustration encountered by workers rendering family preservation services in a multidisciplinary setting as a result of lack of cooperation and coordination of services. Clearly, the absence of the requisite tools makes the realisation of family preservation goals unattainable.

\section{THEME 3: The impact of the challenges and barriers to service delivery on the participants}

The participants reported the emotional drain and trauma resulting from the types of cases they handle.

"When you go home, you feel emotionally drained and feel as if you went through a whole lot of trauma and you re-experience those situations yourself."

"You just think...this child murdered someone... you are also a human being... at the end of the day, it gets to [affects] you... Sometimes you come back to the office after handling such a case and another one is waiting for you."

In a study conducted by Pistorius, Feinauer, Harper, Stahmann and Miller (2008:186), service providers expressed feelings of being traumatised by their clients' stories and tired when they are supposed to attend to clients. Likewise, Van Heugten (2011:11-12) established that when social workers spend a lot of time with traumatised clients they experience vicarious trauma and compassion fatigue.

One participant said: “...we also get burnout from our work." This phenomenon has been reported by Earle (2008b:32), who found increased incidents of burnout among social workers. Because of their experiences of trauma, exhaustion and burnout, some 
participants reported an urge to change their field of work. As stated by one participant: "I feel that I need a change. Maybe, if I can go and work at a school as a school social worker...." The high incidence of staff turnover among social workers because of high caseloads and pressure to deliver services has been noted (Patel et al., 2012:223).

\section{DISCUSSION}

The primary aim of the study was to explore and describe challenges experienced by social workers when providing family preservation services in the Ekurhuleni Metropolitan area. The findings confirmed the existence of myriad challenges previously identified as related to lack of training, inadequate leadership, unrealistic expectations of the DSD, lack of resources or funding and low salaries (Bak, 2004:83; Gray \& Lombard, 2008:135; Landman \& Lombard, 2006:2; Mashigo, 2007:90; Matthias \& Zaal, 2009:295), and burnout among social workers. The fact that guidelines on family preservation services are not clear and that social workers are confused about what family preservation services should entail means that social workers may also be uncertain about the different types of services, including which cases are suitable for family preservation services.

The corroboration from previous studies (Dlangamandla, 2010; Earle, 2008b; Landman \& Lombard, 2006; Mashigo, 2007; Strydom, 2010) implies that not much has been done by those in authority to ameliorate the problems. The National DSD is lauded for the development and implementation of the recruitment and retention strategy which seeks to address the shortage of social workers in South Africa. Nevertheless, the persistence of the challenges in family preservation services calls for an in-depth investigation of the efforts made by policy-makers. Social workers should enhance collaboration with the police and health professionals as they play a vital role in family preservation. Furthermore, they should conduct continuous educational campaigns to encourage parents to respect the children's court ruling by participating in the family preservation programme. To allay the parents' fears about their roles and functions, educational campaigns should include a marketing strategy to publicise their services through road shows and flyers written in indigenous languages, for instance isiZulu and Tswana. Increased community awareness will transform and encourage communities to report neglect and abuse of children to relevant authorities.

\section{CONCLUSION}

Even though the findings seem to convey a bleak picture about the delivery of family preservation services and the plight of social workers, some social workers are still determined to deliver services against all odds. As generalists, they are expected to offer services to diverse groups, hence they are unable to cope with the high caseloads. Considering the host of challenges faced by social workers at different levels when providing family preservation services in Ekurhuleni, it has been concluded that effective family preservation services cannot be offered without the required human, communal, financial resources and organisational support required for the success of the programme. 
Unless drastic measures are taken by employers to address the shortage of social workers, provision of support and resources to address numerous challenges faced by parents of vulnerable children through family preservation services will remain inadequate.

Suggested future research should focus on the following areas:

- To determine possible effective ways of addressing the challenges identified in this study;

- To conduct studies to determine the perceptions of families on the effectiveness of family preservation services;

- To explore and determine the monitoring and evaluation of family preservation programmes, including the implications for social work practice;

- To determine ways to improve social workers' wellbeing.

\section{REFERENCES}

ANDERSON, K.M. 2013. Assessing strengths: identifying acts of resistance to violence and oppression. In: SALEEBEY, D. (ed) The strengths perspective in social work practice $\left(6^{\text {th }} \mathrm{ed}\right)$. Boston: Pearson.

BAK, M. 2004. Can developmental social welfare change an unfair world?: the South African experience. International Social Work, 47(1):81-94.

BAILEY, D.B., RASPA, M. \& FOX, L.C. 2012. What is the future of family outcomes and family-centered services? Topics in Early Childhood Special Education, 31(4):216-223.

BERRY, M. 2005. Overview of family preservation. In: MALLON, G.P. \& HESS P.M. (eds) Child Welfare for the twenty-first century: a handbook of practices, policies, and program. New York: Columbia University Press.

BIRKENMAIER, J., BERG-WEGER, M. \& DEWEES, M. 2011. The practice of generalist social work $\left(2^{\text {nd }}\right.$ ed $)$. New York: Routledge.

BYWATER, J. 2008. Working effectively with children and families in safeguarding the children arena. In: O'LOUNGHLIN, M. \& O'LOUNGLIN, S. (eds) Transforming social work practice: social work with children and families $\left(2^{\text {nd }}\right.$ ed $)$. Exeter: Learning Matters Limited.

CASH, S.J. 2008. Family preservation services. In: COADY, N. \& LEHMAN, P. (eds) Theoretical perspectives for direct social work practice: a generalist-eclectic approach $\left(2^{\text {nd }}\right.$ ed). New York: Springer Publishing Company.

CASH, S.J. \& BERRY, M. 2003. The impact of family preservation services on child and family well-being. Journal of Social Services Research, 29(3):1-26.

CITY OF EKURHULENI.2013. Ekurhuleni Annual Report 2012/13. [Online] Available: $\quad$ www.ekurhuleni.gov.za/519-annual-report-201213-lower-resolution/file. [Rev. 02/02/2014. 
COCK, L. 2008. Transformational challenges facing contemporary social work: an exploratory study. Pretoria: University of South Africa. (MA dissertation)

COLLINS, D., JORDAN, C. \& COLEMAN, H. 2010. An introduction to family social work $\left(3^{\text {rd }}\right.$ ed). Belmont: Brooks/Cole.

COLLINS, D., JORDAN, C. \& COLEMAN, H. 2007. An introduction to family social work $\left(2^{\text {nd }}\right.$ ed). Belmont: Brooks/Cole.

COLLINS, S. 2008. Statutory social workers: stress, job satisfaction, coping, social support and individual difference. British Journal of Social Work, 38:1173-1193.

COULSHED, V. \& ORME, J. 2012. Social work practice $\left(5^{\text {th }}\right.$ ed). Hampshire: Palgrave Macmillan.

CRESWELL, J.W. 2009. Research design: qualitative, quantitative, and mixed methods approaches $\left(3^{\text {rd }}\right.$ ed $)$. London: Sage Publications.

CROSSON-TOWER, C. 2009. Exploring child welfare: a practice perspective $\left(5^{\text {th }}\right.$ ed). Boston: Pearson Education.

DAVIDS, N. 2012. Funding crisis for NPOs. The Times, 14 May, 6.

DEPARTMENT OF SOCIAL DEVELOPMENT NATIONAL STRATEGIC PLAN. 2013. Ministry for the Department of Social Development. Pretoria: Republic of South Africa. Unpublished Paper.

DLANGAMANDLA, V.P. 2010. The experiences of social workers regarding the implementation of a developmental social welfare approach within the Department of Social Development Gauteng Province. Pretoria: University of Pretoria. (MA dissertation)

DOWNS, S.W., MOORE, E., McFADDEN, E.J., MICHAUD, S.M. \& COSTIN, L.B. 2004. Child welfare and family services: policies and practice $\left(7^{\text {th }}\right.$ ed). Boston: Pearson Education.

DURRHEIM, K. 2006. Research design. In: TERRE BLANCHE, M., DURRHEIM, K. \& PAINTER, D. (eds) Research in practice: applied methods for social sciences. Cape Town: UCT Press.

EARLE, N. 2008a. Social work as a scarce and critical profession: scarce \& critical skills research project. Research Commissioned by the Department of Labour South Africa.

EARLE, N. 2008b. Social work in social change: the profession and education of social workers in South Africa. Cape Town: HSRC Press.

EKURHULENI WELFARE, SOCIAL SERVICES AND DEVELOPMENT FORUM. 2012a. Monthly forum meeting. 26 March. Benoni.

EKURHULENI WELFARE, SOCIAL SERVICES AND DEVELOPMENT FORUM. 2012b. Monthly forum meeting. 07 May. Benoni.

E-TV. 2012. Seven o'clock news. [SABC TV programme]. 19 April. 
GANDARILLA, A.H. 2009. Family preservation: a content analysis of literature. Long Beach: California State University. (M dissertation)

GRAY, M. \& LOMBARD, A. 2008. The post-1994 transformation of social work in South Africa. The International Journal of Social Welfare, 17:132-145.

GREEN PAPER ON FAMILIES: PROMOTING FAMILY LIFE AND STRENGTHENING FAMILIES IN SOUTH AFRICA. 2011. Ministry for the Department of Social Development. Government Gazette, Vol. 3, No. 34657 (3 October). Pretoria: Government Printer.

GROCKEL, A., RUSSELL, M. \& HARRIS, B. 2008. Recreating family: parents identify worker-client relationships as paramount in family preservation programs. Child Welfare Journal, 87(6):91-113.

HALL, K. 2013. Income poverty, unemployment and social grants. In: BERRY, L., BIERSTEKER, L. DAWES, A., LAKE, L. \& SMITH, C. (eds) South African child gauge 2013. University of Cape Town: Children's Institute, 90-94.

HENNINK, M., HUTTER, I. \& BAILEY, A. 2011. Qualitative research methods. Los Angeles: Sage Publications.

HOLLAND, S. 2011. Child \& family assessment in social work practice $\left(2^{\text {nd }}\right.$ ed $)$. Los Angeles: Sage Publications.

INTEGRATED SERVICE DELIVERY MODEL. 2006. Ministry for the Department of Social Development. Pretoria: Department of Social Development.

JANZEN, C., HARRIS, O., JORDAN, C. \& FRANKLIN, C. 2006. Family treatment: evidence-based practice with populations at risk $\left(4^{\text {th }}\right.$ ed). Australia: Thomson Brooks/Cole.

JONES, F. \& MORRIS, M. 2007. Working with sexual abuse: a systemic perspective on whether children need to tell their therapist details of the abuse for healing to take place. Journal of Family Therapy, 29:222-237.

KRANE, J., DAVIS, L., CALTON, R. \& MULCAHY, M. 2010. The clock starts now: feminism, mothering and attachment theory in child protection practice. In: FEATHERSTONE, B., HOOPER, C.A., SCOURFIELD, J. \& TAYLOR, J. (eds) Gender and child welfare in society. London: Wiley Blackwell.

LANDMAN, L. \& LOMBARD, A. 2006. Integration of community development and statutory social work services within the developmental approach. Social Work/Maatskaplike Werk, 42:1-15.

LAW, M., HANNA, S., KING, G., HURLEY, P., KING, S., KERTOY, M. \& ROSENBAUM, P. 2003. Factors affecting family-centred service delivery for children with disabilities. Child: Care, Health \& Development, 29(5):357-366.

MADSEN, W.C. 2009. Collaborative helping: a practice framework for family-centered services. Family Process, 48(1):103-116. 
MACCIO, E.M., SKIBA, D., DOUECK, H.J., RANDOLPH, K.A., WESTON, E.A. \& ANDERSON, L.E. 2003. Social workers perceptions on family preservation programs. Family Preservation Journal, 7:1-18.

MANUAL ON FAMILY PRESERVATION SERVICES. 2010. Ministry for Department of Social Development. 2010. Pretoria: Department of Social Development.

MARSHALL, C. \& ROSSMAN, G.B. 2011. Designing qualitative research (5 ${ }^{\text {th }}$ ed). Los Angeles: Sage Publications.

MASHIGO, B.P. 2007. Social workers' experiences on the transformation of social welfare from remedial approach to developmental approach. Port Elizabeth: Nelson Mandela Metropolitan University. (MA dissertation)

MATTHIAS, C.R. \& ZAAL, F.N. 2009. Supporting familial and community care for children: legislative reform and implementation challenges in South Africa. International Journal of Social Welfare, 18:291-298.

MINISTER PROBES NGOS' FUNDING CRISIS. 2012. The New Age, 27 June, 22.

MONETTE, D.R., SULLIVAN, T.J. \& DEJONG, C.R. 2008. Applied social research: a tool for the human services $\left(8^{\text {th }} \mathrm{ed}\right)$. London: Thompson Brooks/Cole.

PATEL, L. 2005. Social welfare and social development in South Africa. Cape Town: Oxford University Press.

PATEL, L., SCHMID, J. \& HOCHFELD, T. 2012. Transforming social work services in South Africa: perspectives of NPO managers. Administration in Social Work, 36:212230.

PISTORIUS, K.D., FEINAUER, L.L., HARPER, J.M., STAHMANN, R.F. \& MILLER, R.B. 2008. Working with sexually abused children. The American Journal of Family Therapy, 36:181-195.

POPPLE, P.R. \& LEIGHNINGER, L. 2008. The policy based profession: an introduction to social welfare policy analysis for social workers $\left(4^{\text {th }} \mathrm{ed}\right)$. Boston: Pearson Education.

RAVESTIJN, S. 2001. Inanda family preservation project, Inanda, Durban. Mission Report. [Online] Available: www.unhabitat.org/downloads/docs/1842_30620_inanda. pdf. [Rev: 18/06/2012].

RECRUITMENT AND RETENTION STRATEGY FOR SOCIAL WORKERS IN SOUTH AFRICA. 2006. Ministry for the Department of Social Development. Pretoria: Department of Social Development.

REPETTI, R.L., TAYLOR, S.E. \& SEEMAN, T.E. 2002. Risky families: family social environments and the mental and physical health of offspring. Psychological Bulletin, 128(2):330-336.

REPUBLIC OF SOUTH AFRICA. 2006. Children's Act (Act No. 38) of 2005. Government Gazette, Vol. 492 No. 28944, (19 June). 
ROYSE, D. 2008. Research methods in social work (5th ed). Australia: Thomson Brooks/Cole.

RUBIN, A. \& BABBIE, E. 2010. Essential research methods for social work (2 $\left.2^{\text {nd }} \mathrm{ed}\right)$. Belmont: Brooks/Cole.

RYCUS, J.S. \& HUGHES, R.C. 2008. Assessing risk throughout the life of a child welfare case. In: LINDSEY, D. \& SHLONSKY, A. (eds) Child welfare research: advances for practice and policy. New York: Oxford Scholarship.

SALEEBEY, D. 2013. Introduction: power in the people. In: SALEEBEY, D. (ed) The strengths perspective in social work practice $\left(6^{\text {th }}\right.$ ed). Boston: Pearson, 1-23.

SANDOVAL. C. 2010. Children's social workers' experiences and perceptions on the family preservation program. Long Beach: California State University. (M dissertation)

SEWPAUL, V. \& HÖLSCHER, D. 2007. Against the odds: community-based interventions for children in difficult circumstances in post-apartheid South Africa. In: DOMINELLI, L. (ed) Revitalising communities in a globalising world. Aldershot: Ashgate Publishing Limited.

SITHOLE, S. 2010. Marginalisation of social workers in South Africa: some reflections from a feminist perspective. The Social Work Practitioner-Researcher, 22(1):6-19.

SOUTH AFRICAN INSTITUTE OF RACE RELATIONS. 2011. First steps to healing the South African family. Johannesburg: South African Institute of Race Relations.

STATISTICS SOUTH AFRICA. 2012. Census 2011 Municipal Report Gauteng. Pretoria: Statistics South Africa.

STRYDOM, M. 2010. The implementation of family preservation services: perspectives of social workers at NGOs. Social Work/Maatskaplike Werk, 46(2):192-208.

SWART, H. 2012. A broken system cannot fix the broken people. Mail \& Guardian, June 28:24.

TULLY, L. 2008. Family preservation services: literature review. Research Report. Ashfield NSW: Centre for Parenting and Research Services System Development.

VAN HEUGTEN, K. 2011. Social workers under pressure: how to overcome stress, fatigue and burnout in the work place. London: Jessica Kingsley Publishers.

VIOLENCE AGAINST CHILDREN IN SOUTH AFRICA. 2012. Ministry for the Department of Social Development. Pretoria: Department of Social Development.

WALKER, J. \& CRAWFORD, K. 2010. Transforming social work practice: social work and human development. Exeter: Learning Matters.

WHITE PAPER ON FAMILIES IN SOUTH AFRICA. 2012. Ministry for the Department of Social Development. Pretoria: Government Printer.

WHITE PAPER FOR SOCIAL WELFARE: PRINCIPLES, GUIDELINES, RECOMMENDATIONS, PROPOSED POLICIES AND PROGRAMMES FOR 
DEVELOPMENTAL SOCIAL WELFARE IN SOUTH AFRICA. 1997. Ministry for the Department of Welfare. 1997. Government Gazette, Vol. 386, No. 18166 (8 August). Pretoria: Government Printer.

YEGIDIS, B.L. \& WEINBACH, R.W. 2002. Research methods for social workers $4^{\text {th }}$ ed). Boston: Allyn \& Bacon.

ZASTROW, C. 2008. Introduction to social work and social welfare: empowering people $\left(9^{\text {th }}\right.$ ed). United States: Thomson Brooks/Cole.

Ms Felistas Nhedzi; Prof Mankwane Makofane, Department of Social Work, University of South Africa, Pretoria, South Africa. 